$\mathrm{Nr} 6$

KRAKÓW 2003
WARSZAWA-
ANDRZEJ WIELOŃSKI

Uniwersytet Warszawski

\title{
Przemysł Nowej Gospodarki
}

W drugiej połowie XX wieku nauka przekształciła się w bezpośrednią siłę wytwórczą. Dotychczasowe dwa etapy procesu produkcji: inwestycja i produkcja, zostały rozszerzone o trzeci, poprzedzający je etap badań naukowych i prac rozwojowych - R+D (Research and Development). W Stanach Zjednoczonych, Japonii, Korei, Izraelu i wielu krajach Europy Zachodniej udział nakładów na $\mathrm{R}+\mathrm{D}$ zwiększył się do 2-3\% produktu krajowego brutto (w Szwecji - 3,7\%), natomiast ich wartość w przeliczeniu na jednego pracownika naukowego - do 200-300 tys. USD (w Szwajcarii - 322 tys. USD).

Oprócz wzrostu nakładów znaczącą rolę w tym procesie odegrało wykorzystanie w gospodarce wyników badań realizowanych dla potrzeb wojska ${ }^{*}$ oraz druga rewolucja uniwersytecka* ${ }^{* *}$.

Przejawem tej ostatniej jest współpraca wyższych uczelni charakteryzujących się innowacyjną agresywnością z powstającymi wokół nich licznymi małymi przedsiębiorstwami naukowo-produkcyjnymi zakładanymi przez profesorów, doktorantów i studentów wykorzystujących do tego celu zróżnicowane źródła finansowania, w tym kapitał ryzyka. Jej symbolem stała się Dolina Krzemowa w Kalifornii, której centrum stanowi Uniwersytet Stanforda w Palo Alto.

Spektakularnym efektem przekształcenia się nauki w bezpośrednią siłę wytwórczą było powstanie przemysłów wysokiej techniki (high-technology industries), charakteryzujących się znaczną intensywnością (zawartością) $\mathrm{R}+\mathrm{D}$ w relacji do sprzedaży, w tym zwłaszcza powstanie przemysłu informatycznego (produkcja komputerów i oprogramowania, usługi informatyczne).

Przemysł informatyczny należy do najmłodszych gałęzi przemysłu. W latach sześćdziesiątych powstały komputery główne, w latach osiemdziesiątych - komputery osobiste, natomiast w latach dziewięćdziesiątych - sieci komputerowe.

Powstanie przemysłu informatycznego jest porównywane z przełomem w rozwoju ludzkości, jakim było wynalezienie i zastosowanie maszyny parowej - symbolu pierwszej

* Do innowacji, które zostały następnie szeroko upowszechnione w sferze cywilnej należą m.in.: teflon - tworzywo niepalne do wyrobu naczyń kuchennych, goretex - termoaktywna tkanina ubraniowa, i sztuczne serce, w którego budowie wykorzystano technologię zastosowaną w pompach paliwowych promów kosmicznych.

** Pierwszą rewolucją uniwersytecką było podjęcie badań naukowych przez wyższe uczelnie na początku XIX W. 
rewolucji przemysłowej (powstanie przemysłu fabrycznego w drugiej połowie XVIII w.), a następnie transportowej (upowszechnienie się transportu kolejowego w XIX w.).

Jednak zasięg informatyki jest znacznie szerszy. Technologie informatyczne znalazły szerokie zastosowanie w aparaturze naukowo-badawczej, telekomunikacji, środkach masowego przekazu, aparaturze i urządzeniach medycznych, sprzęcie automatyki przemysłowej i pracy biurowej, nowych generacjach broni i transporcie.

Współczesna rewolucja przemysłowa jest jednocześnie rewolucją telekomunikacyjna. W latach dziewięćdziesiątych XX w. najszybciej rozwijającym się działem telekomunikacji stała się łączność ruchoma za pośrednictwem telefonów komórkowych. Telefony komórkowe, które początkowo służyły wyłącznie do prowadzenia rozmów, zostały dodatkowo wyposażone w możliwość transmisji danych, a następnie - danych multimedialnych. W 2001 r. liczba ich użytkowników na świecie przekroczyła 1 miliard.

Pod koniec XX w. wykorzystanie technologii informatyczno-telekomunikacyjnych ICT (Information and Communication Technologies) stało się w krajach wysoko rozwiniętych czynnikiem dynamizującym rozwój gospodarki i źródłem postępu cywilizacyjnego społeczeństwa.

Jego efektem jest przyspieszenie budowy Nowej Gospodarki (new economy), nazywanej również gospodarką opartą na wiedzy (knowledge economy), w której nakłady na informatykę i telekomunikację są istotnym (obok produktu krajowego brutto) miernikiem rozwoju społeczno-gospodarczego.

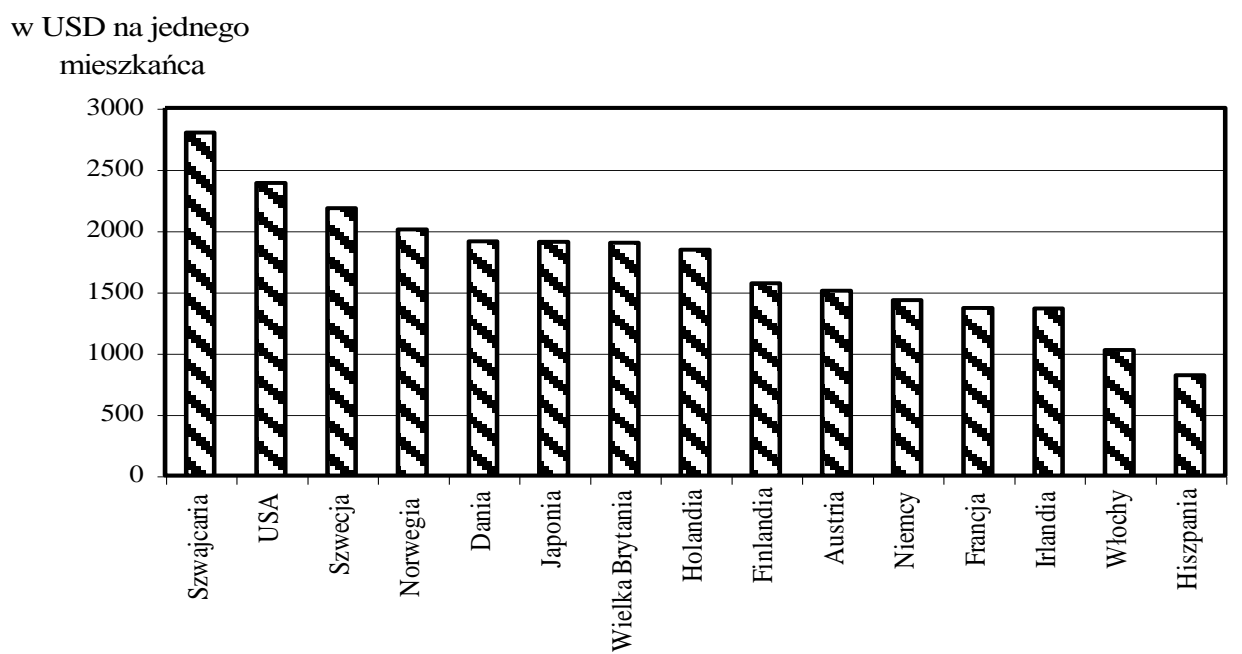

Ryc. 1. Nakłady na informatykę i telekomunikację w $2000 \mathrm{r}$.

Integracja technologii informatycznych i telekomunikacyjnych doprowadziła do stworzenia Internetu, wykorzystywanego początkowo w placówkach naukowo-badawczych i do kształcenia kadr. Upowszechnienie się komputerów osobistych i zastosowanie modemów urządzeń umożliwiających przesyłanie różnych informacji łączami telefonicznymi - przyczyniło się do przekształcenia Internetu w sieć globalną. Liczba jego użytkowników na świecie zwiększyła się z 16 mln w 1995 r. do ponad 544 mln na początku 2002 r.

Dostęp do Internetu, umożliwiając bardziej sprawną koordynację działalności produkcyjnej, usługowej, handlowej i badawczej zagranicznych filii z jednego ośrodka podej- 
mującego strategiczne decyzje (kompresja czasu i przestrzeni), umocnił pozycję korporacji jako wiodącej grupy podmiotów w gospodarce światowej. W 2001 r. na 100 największych gospodarek świata 29 stanowiły korporacje.

Oprócz tradycyjnych aktywów materialnych (kapitału rzeczowego i kapitału finansowego) dysponują one nowoczesnymi aktywami niematerialnymi - kapitałem intelektualnym. Obejmuje on wiedzę menedżerską wykorzystywaną w zarządzaniu, wiedzę marketingową wykorzystywaną w zdobywaniu, utrzymaniu lub rozszerzaniu rynku oraz wiedze technologiczną wykorzystywaną w prowadzeniu badań naukowych i prac rozwojowych* Wartość tych aktywów zwiększa się w wyniku łączenia się (fuzji, przejęć) przedsiębiorstw i zawierania strategicznych sojuszy (aliansów) dla wspólnego prowadzenia określonej działalności.

Cechą charakterystyczną korporacyjnej formy przedsiębiorstw jest zdolność do ekspansji przejawiająca się w bezpośrednich inwestycjach zagranicznych (BIZ) - nakładach kapitałowych dokonywanych $\mathrm{w}$ przedsiębiorstwach zagranicznych $\mathrm{w}$ celu uruchomienia ich od podstaw (greenfield investment) albo ich zakupu w części lub w całości. Przedmiotem tych transakcji są zarówno przedsiębiorstwa kooperujące, jak i konkurujące. Zjawisko to nabrało szczególnych rozmiarów pod koniec XX w. W latach 1990-2000 roczna wartość BIZ zwiększyła się prawie dziesięciokrotnie.

W 2000 r. 60 tys. korporacji posiadających 800 tys. filii zainwestowało 1490 mld USD; rok później - zaledwie 735 mld USD. Istotny wpływ miał na to spadek w $2001 \mathrm{r}$. liczby (o 32\%) i wartości (o 60\%) transakcji (fuzje, przejęcia), mających znaczny udział w BIZ, zwłaszcza reprezentujących Nową Gospodarkę. W tym ostatnim przypadku był to przede wszystkim rezultat urealnienia cen akcji, których kurs w latach poprzednich był oderwany (znacznie wyższy) od ich rzeczywistej wartości, do czego bez wątpienia przyczyniła się bezkrytyczna fascynacja inwestorów giełdowych technologiami informatycznoteleko-munikacyjnymi. Z kolei nadmierny optymizm przedsiębiorców, wyrażający się w zbyt dużych zakupach sieci światłowodowych, doprowadził do poważnego zadłużenia firmy telekomunikacyjne, a w konsekwencji do spadku kursu ich akcji.

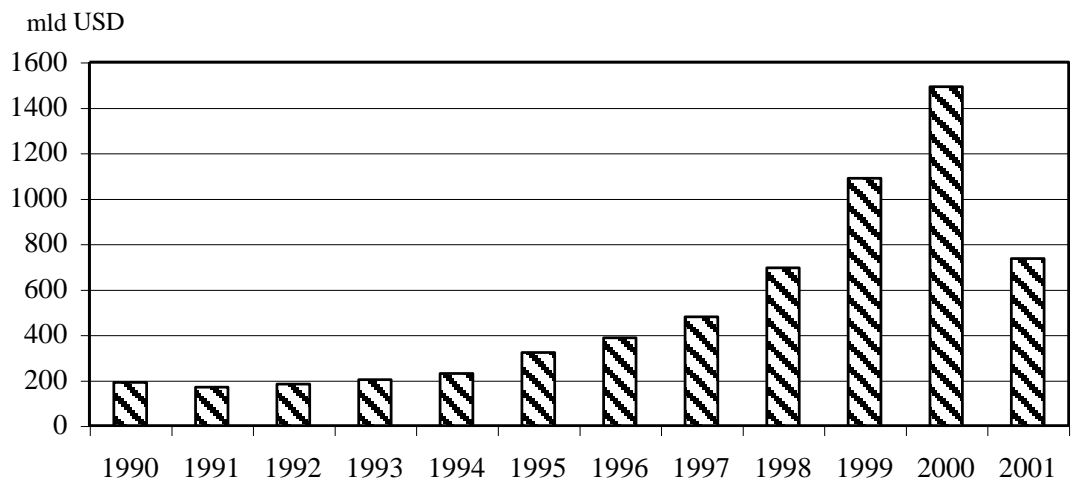

Ryc. 2. Napływ bezpośrednich inwestycji zagranicznych na świecie

W 2001 r. wartość przychodów 100 największych korporacji wyniosła 4797 bln USD. Tradycyjnie do największych należą korporacje przetwarzające ropę naftową i produkujące

* W połowie XX w. aktywa niematerialne stanowiły 22\% wartości amerykańskich korporacji spoza sektora finansowego, obecnie $-47 \%$. 
samochody. Przyśpieszeniu budowy Nowej Gospodarki towarzyszy ekspansja firm produkujących sprzęt telekomunikacyjny, komputery i urządzenia peryferyjne, oprogramowanie i półprzewodniki, firm zajmujących się ich dystrybucją, firm świadczących usługi informatyczne i telekomunikacyjne oraz firm internetowych.

Tabela 1. Największe firmy informatyczne i telekomunikacyjne

\begin{tabular}{|l|c|c|}
\hline \multicolumn{1}{|c|}{ Firma } & Kraj & $\begin{array}{c}\text { Przychody } \\
\text { w mln USD }\end{array}$ \\
\hline IBM & USA & 83373,0 \\
\hline Verizon Communications & USA & 67299,0 \\
\hline SBC Communications & USA & 45240,0 \\
\hline Deutsche Telekom & Niemcy & 43582,4 \\
\hline Hewlett-Packard & USA & 43164,0 \\
\hline NTT DoCoMo & Japonia & 41414,1 \\
\hline Motorola & USA & 36495,0 \\
\hline Samsung Electronics & Korea & 35025,5 \\
\hline Vodafone Group & Wielka Brytania & 32793,2 \\
\hline Dell Computer & USA & 31206,0 \\
\hline
\end{tabular}

Źródło: „Business Week” 2002, nr 7, s. 62-72

Spośród największych korporacji Nowej Gospodarki tylko dwie: Samsung Electronics i Dell Computer znalazły się w grupie najlepszych firm informatycznych i telekomunikacyjnych.

Tabela 2. Najlepsze firmy informatyczne i telekomunikacyjne

\begin{tabular}{|l|l|c|c|c|c|}
\hline \multicolumn{1}{|c|}{ Firma } & Kraj & $\begin{array}{c}\text { Przychody } \\
\text { w mln USD }\end{array}$ & $\begin{array}{c}\text { Zmiana przy- } \\
\text { chodów w \% }\end{array}$ & $\begin{array}{c}\text { Zwrot } \\
\text { kapitału } \\
\text { w \% }\end{array}$ & $\begin{array}{c}\text { Zwrot } \\
\text { dla akcjona- } \\
\text { riuszy w \% }\end{array}$ \\
\hline Samsung Electronics & Korea & 35025,5 & 6,7 & 15,8 & 69,5 \\
\hline Quanta Computer & Tajwan & 3304,3 & 34,8 & 29,0 & 15,8 \\
\hline Hon Hai Precision Industry & Tajwan & 4557,4 & 57,3 & 23,1 & $-1,9$ \\
\hline KT Freetel & Korea & 3481,4 & 61,7 & 20,1 & 8,6 \\
\hline Dell Computer & USA & 31206,0 & $-4,4$ & 27,5 & 10,2 \\
\hline China Mobile & Chiny & 12121,8 & 54,4 & 25,1 & $-35,3$ \\
\hline Affiliated Computer Services & USA & 2756,6 & 35,0 & 9,8 & 54,0 \\
\hline Elite Group Computer Systems & Tajwan & 957,3 & 65,0 & 26,1 & 54,1 \\
\hline SK Telecom & Korea & 4740,9 & 8,1 & 20,1 & 29,6 \\
\hline L-3 Communications Holdings & USA & 2582,4 & 29,4 & 10,3 & 42,6 \\
\hline
\end{tabular}

Źródło: „Business Week” 2002, nr 7, s. 62-72

Pierwsze miejsce zajmuje Samsung Electronics, którego zadłużenie jeszcze w 1997 r. przekraczało 2,5-krotnie wartość jego majątku. Efektem przeprowadzonej restrukturyzacji, w ramach której zmniejszono do 2001 r. zatrudnienie z 80 tys. do 45 tys. osób, natomiast zwiększono do $725 \mathrm{mln}$ USD nakłady na $\mathrm{R}+\mathrm{D}$ i prawie tyle samo na marketing, rezygnując równocześnie z kupowania licencji japońskich, jest przekształcenie się firmy z imitatora/modyfikatora w innowatora/lidera produktu. Samsung Electronics stał się światowym producentem: układów pamięci (26,3\% rynku), płaskich kineskopów, telefonów komórko- 
wych i wielu innych wyrobów wysokiej techniki. W 2001 r. zadłużenie stanowiło już tylko $20 \%$ wartości majątku firmy.

W grupie najlepszych znajdują się trzy firmy z Tajwanu posiadające filie w Chinach: Quanta Computer - producent notebooków oraz Hon Hai Precision Industry i Elite Group Computer Systems - producenci podzespołów do komputerów osobistych. Tak wysoką pozycję zawdzięczają one decyzjom wielkich koncernów informatycznych, głównie ze Stanów Zjednoczonych, które dążąc do obniżenia kosztów przenoszą część produkcji do krajów

o niższych kosztach pracy. Dla porównania: w drugiej połowie lat dziewięćdziesiątych XX w. roczne wynagrodzenie inżyniera - projektanta układów scalonych w Kalifornii wynosiło 60-100 tys. USD, na Tajwanie -25 tys. USD, natomiast w Chinach -10 tys. USD. W tym ostatnim przypadku inżynier-projektant był równocześnie doktorem nauk technicznych.

Pozostałe firmy azjatyckie: KT Freetel i SK Telecom z Korei oraz China Mobile z Chin - to operatorzy bardzo szybko rozwijającej się telefonii komórkowej.

Oprócz firm azjatyckich wśród najlepszych znalazły się również trzy korporacje ze Stanów Zjednoczonych: Dell Computer - światowy producent komputerów osobistych (ponad 11\% rynku) i serwerów (ponad 15\% rynku), L-3 Communications Holdings - producent sprzętu telekomunikacyjnego dla przemysłu obronnego, na którego zapotrzebowanie gwałtownie wzrosło po 11 września 2001 r. oraz Affiliated Computer Services świadczący $\mathrm{w}$ ramach outsorcingu (przekazywanie części prac przedsiębiorstwa na zewnątrz,

w celu obniżenia kosztów) usługi w zakresie prac administracyjno-biurowych.

Przyspieszenie budowy Nowej Gospodarki w drugiej połowie lat dziewięćdziesiątych było $\mathrm{z}$ jednej strony efektem upowszechnienia się technologii informatyczno-telekomunikacyjnych, z drugiej - wzrostu wartości bezpośrednich inwestycji zagranicznych w przemysłach wysokiej techniki. Stworzyło to szczególnie korzystne warunki dla ekspansji gospodarczej korporacji transnarodowych, w tym zwłaszcza informatycznych i telekomunikacyjnych. Korporacje te stały się głównymi podmiotami i beneficjentami Nowej Gospodarki.

Rosnąca rola kapitału intelektualnego w ekonomice przedsiębiorstw oraz zorientowanie na rynek światowy (lokalizacja produkcji w regionach o najniższych kosztach pracy, równoczesne uruchamianie produkcji w krajach o zróżnicowanym poziomie rozwoju społeczno-gospodarczego) są podstawą ich przewagi konkurencyjnej. Przewaga ta rośnie w efekcie procesów restrukturyzacyjnych przedsiębiorstw w obszarach: techniki i technologii organizacji i zarządzania oraz ekonomiki i rynku. Dotyczy to wszystkich korporacji informatycznych i telekomunikacyjnych, zarówno $\mathrm{z}$ krajów wysoko rozwiniętych, jak i z nowo uprzemysłowionych krajów azjatyckich - zaliczanych do światowych firm przemysłowych (world class manufacturing). 